\title{
QUANTIFYING THE ECONOMIC DEVELOPMENT DYNAMICS OF A COUNTRY BASED ON THE LORENZ CURVE
}

\author{
Romualdas Ginevičius', Joanicjusz Nazarko², \\ Dainora Gedvilaité ${ }^{3}$, Zdzisława Dacko-Pikiewicz ${ }^{4}$
}

1 Vilnius Gediminas Technical University, Faculty of Business Management, Institute of Dynamic Management, Lithuania, ORCID: 0000-0003-2067-4398, romualdas.ginevicius@vgtu.lt;

2 Bialystok University of Technology, Faculty of Engineering Management, Poland, ORCID: 0000-0002-0236-2334, j.nazarko@pb.edu.pl;

3 Vilniaus Kolegija/University of Applied Sciences, Faculty of Economics, Department of Finance, Lithuania, ORCID: 000-0001-5813-0607, d.gedvilaite@ekf.viko.It;

4 WSB University, Faculty of Applied Sciences, Poland, ORCID: 0000-0003-4542-5574, zdacko@wsb.edu.pl.

\begin{abstract}
The welfare of a country depends on its economic development. In order to have the impact on it, we should have a possibility to quantitatively assess its situation at the desired point in time. Economic development, as a multifaceted and complex phenomenon, is reflected in two dimensions - intensity and uniformity. These mentioned above can be viewed as partial indicators of dynamics. Two main approaches to measuring development uniformity can be distinguished. In one of the cases, it is measured on the basis of an index that includes the main results of the country's economic development. In the other case, the values of the indicators reflecting all the essential development actions are combined in one appropriate way. From a scientific point of view, the second approach is more accurate as it allows for a better assessment of the complex nature of a country's economic development. On the other hand, its application today is still problematic due to the fact that the models for this differ in terms of both the number and composition of indicators. For this reason, it is not possible to compare countries. Therefore, in international practice, the economic development of countries is measured by gross domestic product per capita (GDP). Based on GDP indicator, the method for the measurement of uniformity is proposed and the essence of which is the ratio of the length of the ideal trajectory of the development during the period under review to the length of the actual trajectory. Without ruling out the appropriateness of such an approach for assessing development uniformity, it makes sense to look for alternative methods. In this sense, methods that allow assessment of the extent of fluctuations of the phenomenon under consideration as an essential feature of development dynamics are suitable. These include the Gini coefficient, which is determined from the Lorenz curve.
\end{abstract}

Keywords: Country economic development, quantification of dynamics of economic development, Gini coefficient, Lorenz curve.

JEL Classification: 01, 011.

APA Style Citation: Ginevičius, R., Nazarko, J., Gedvilaitè, D., \& Dacko-Pikiewicz, Z. (2020). Quantifying the Economic Development Dynamics of a Country Based on the Lorenz Curve. E\&M Economics and Management, 24(1), 55-65. https://doi.org/10.15240/tul/001/2021-1-004

\section{Introduction}

Today market players at all levels, from business operators to countries, strive to be competitive. This aspiration is not passive, and is not only about maintaining current positions.
As a result of the global economic development of the world, the growth of global markets forces particular countries to increase the economic scale of the economic growth, otherwise they will lose their positions. The pursuit of 
an increasing share of international markets becomes the basis for a country's competitive capacity. Only by keeping pace with the growth of the single market warranty that they remain competitive. Therefore, development becomes a hallmark of competitiveness.

In this context, it is important for both science and practice to fully analyse the phenomenon of economic development.

The development of any process can be characterized by two characteristics - its intensity and its uniformity (Ginevičius et al., 2018). Intensity of development is the rate of development growth over the period considered, expressed, for example, in years. Steady development reads as fluctuations in the extent of development over the time periods considered. These two dimensions can be seen as sub-indicators of the overall development process. The first indicator reflects upon the quantitative side of the development process, and the second indicators reflects upon the qualitative side. The development process as a whole is reflected by its dynamics, which combines both of the above mentioned indicators. It shows the extent and type of development changes that have taken place over the period under review.

The essence of dynamics as a phenomenon is expressed by the following synonyms of this term in international dictionaries: sustainable, steady, resilient, stable, immovable, solid, immutable, durable, permanent, settled, long-lasting, even, etc. This abundance of understanding of dynamics is integrated by the two dimensions mentioned above-development intensity and development continuity.

In the scientific literature attempts to quantify this phenomenon can be met (Ginevičius et al., 2018). Based on the methodology presented in this study, the dynamics of economic development in some EU countries were determined. This methodology, which is referred to as the MDD method, provides for the integration of uniformity indicator of the development with its intensity indicator. Uniformity is defined as the ratio of the value of the period under consideration to the total length of the actual development trajectory:

$$
D^{T}=\frac{N}{\sum_{t=1}^{n} \sqrt{1-p_{i}^{2}}}
$$

where $D^{T}$ is the indicator of economic development $T$ over the period under consideration, $N$ is the duration of the period under consideration e.g. years; $p_{i}$ is the change in development over the time period $i$ (year) of the time span under review; $n$ is the number of time periods $(i=\overline{1, n})$ of the period under consideration $T$.

The intensity of the development shall be determined as follows:

$$
K_{p}^{T}=\frac{Q_{f}^{T}}{Q_{b}^{T}}
$$

where $K_{p}^{T}$ is the intensity indicator of the country's economic development over the period $T$ under consideration; $Q_{f}^{T}$ is the significance of economic development at the end of period $T$, $Q_{b}^{T}$ is the significance of economic development at beginning of period $T$.

The process of economic development of socio-economic systems (SES) is rather multifaceted, complex and ambiguous, and it makes sense to look for other ways to quantify its dynamics.

\section{Possibilities for Quantifying Sustainability of Country's Economic Development}

The challenge posed - to quantify the dynamics of the country's economic development requires two questions to be answered. First, which principled models are suitable for quantifying the intensity and continuity of the SES development process; secondly, what indicator or indicators can be used to measure these sub-indicators. The measure of the intensity of economic development of a country can be taken as the value expressed by formula (2). The development consistency indicator can be formulated with the following requirements: it must be easy to understand, the information needed for the calculations must be easily accessible, and, most importantly, it must allow comparisons between entities at any level: economy of countries, regions, countries as a whole, group of countries, etc.

The economic development of the countries will be used to test the adequacy of the homogeneity indicator proposed in this study. The analysis of literature sources that examine, measure and compare this phenomenon highlights two principal possibilities. In one 
case it refers to GDP per capita in a territorial unit. It is considered to be a reliable indicator of success, reflecting upon the level of economic development achieved in the country (Charsan, 2013; Čiegis et al., 2010; Bolcárová \& Kološta, 2015; Babu \& Datta, 2015). Otherwise, the economic development of the analyzed objects, usually countries, or their regions, is evaluated relying upon one aggregate value combining a larger number of partial indicators, which in the authors' opinion reflect upon the essential aspects of economic development. Recently, these methods have been increasingly used to quantify phenomena of all kinds. Importance of indicators available on an equal basis or determined by peer review (Song et al., 2017; Turskis, 2018; Turskis et al., 2017; Boggia \& Cortina, 2010; Prascevic \& Prascevic, 2017).

We may consider that multi-criteria assessment of economic development is more accurate compared to GDP per capita, because enlargement itself is a complex process that manifests itself in many aspects. Formalizing them and expressing them as indicators allows a more complex evaluation of the phenomenon under consideration. On the other hand, the possibilities of applying this promising method, for example for comparing countries, are limited by the variety of indicators that are included in the evaluation model and their composition. The number of such indicators varies from several to several dozen in individual cases (Ginevičius et al., 2018; Čiegis et al., 2010). Even when a model is composed of a small number of indicators, their composition is usually different. This depends on a number of circumstances: what aspects of the phenomenon in question are distinguished by the authors; or from access to information needed to calculate values of an indicator, etc. These circumstances make it difficult to use the results of the multi-criteria assessment of economic development for comparing countries. Meanwhile, international databases and statistical yearbooks of countries provide all the necessary information on their economic development on the basis of per capita GDP. Therefore, this study will be based on this indicator (further - GDP).

Two different countries, Switzerland and Italy, have been selected to illustrate the proposed methodology. Switzerland has experienced a steady growth of GDP per capita over the period under review. On the other hand, this process is accompanied by quite noticeable fluctuations in individual time periods (years) of the period under consideration. In Italy, during the period under review, the rate of economic development has hardly increased, but there is no marked fluctuation either (Tab. 1, Fig. 1).

To quantify the continuity of the SES development process methods based on dynamic analysis of processes can be used, which means that they can assess the magnitude of the fluctuation of the phenomenon under consideration, the essential attribute of dynamics, and that allow to be interpreted. To the methods of this kind we may ascribe coefficients used to analyze the continuity of economic and social processes. First and foremost, these would be the methods of assessment of inequalities in income and economy (Amin, 2006; Atkinson et al., 2002; Čiulevičienè et al., 2006a, b; Čiulevičius \& Čiulevičienè, 2008; Ibragimov et al., 2018; Kawachi \& Kennedy, 1999; Kawachi et al., 1999; Kurowska-Pysz et al., 2018).

Alongside the structural coefficients, some special indicators are needed to assess the economic and social inequality of the population (Čiulevičienè, 2006a; Lazutka, 2002). The most commonly used is the Gini coefficient (index). The ratio varies from 0 to 1 or from 0 to 100 per cent. The larger it is, the greater is the inequality. This indicator is widely used in international comparisons. The Gini coefficient is determined from the Lorenz curve (Dagum, 1980; Grusky, 2001; Rudzkienè, 2005;

\section{Tab. 1: Gross domestic product (GDP) per capita in EUR}

\begin{tabular}{l|c|c|c|c|c|c|c|c|c|c}
\hline \multirow{2}{*}{ Country } & \multicolumn{10}{c}{ Years } \\
\cline { 2 - 13 } & $\mathbf{2 0 0 8}$ & $\mathbf{2 0 0 9}$ & $\mathbf{2 0 1 0}$ & $\mathbf{2 0 1 1}$ & $\mathbf{2 0 1 2}$ & $\mathbf{2 0 1 3}$ & $\mathbf{2 0 1 4}$ & $\mathbf{2 0 1 5}$ & $\mathbf{2 0 1 6}$ & $\mathbf{2 0 1 7}$ \\
\hline Italy & 27.6 & 26.4 & 26.8 & 27.3 & 26.7 & 26.5 & 26.7 & 27.2 & 27.9 & 28.5 \\
\hline Switzerland & 49.3 & 50.2 & 56.1 & 63.7 & 65.0 & 64.1 & 65.3 & 74.0 & 72.4 & 72.6 \\
\hline
\end{tabular}




\section{Economics}

\section{Fig. 1: GDP per capita of the countries concerned}

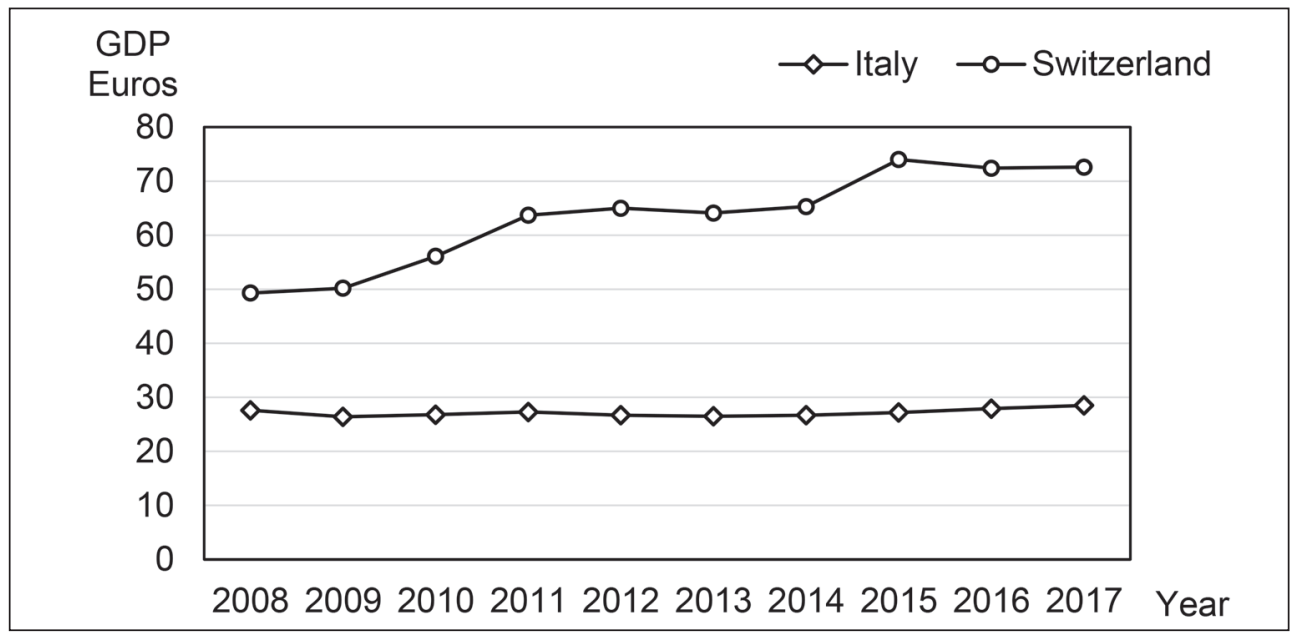

Source: own based on www.eurostat.com

Bratčikovienè \& Deveikytè, 2006; Jann, 2016).

The idea of this curve is that, if it is possible to determine the total inequality of the indicator under consideration, there comes the opportunity to analyze the nature of its distribution between the individual time spans of the period under consideration. For example, to depict graphically the distribution of households by income, they are arranged in ascending order on the axis $X$ of the ordinate system, indicating the percentage of the population (households); meanwhile depicting the deferred percentage of their income in axis $Y$ (Fig. 2).

The nature of the Lorenz curve and the

\section{Fig. 2: Lorenz curve}

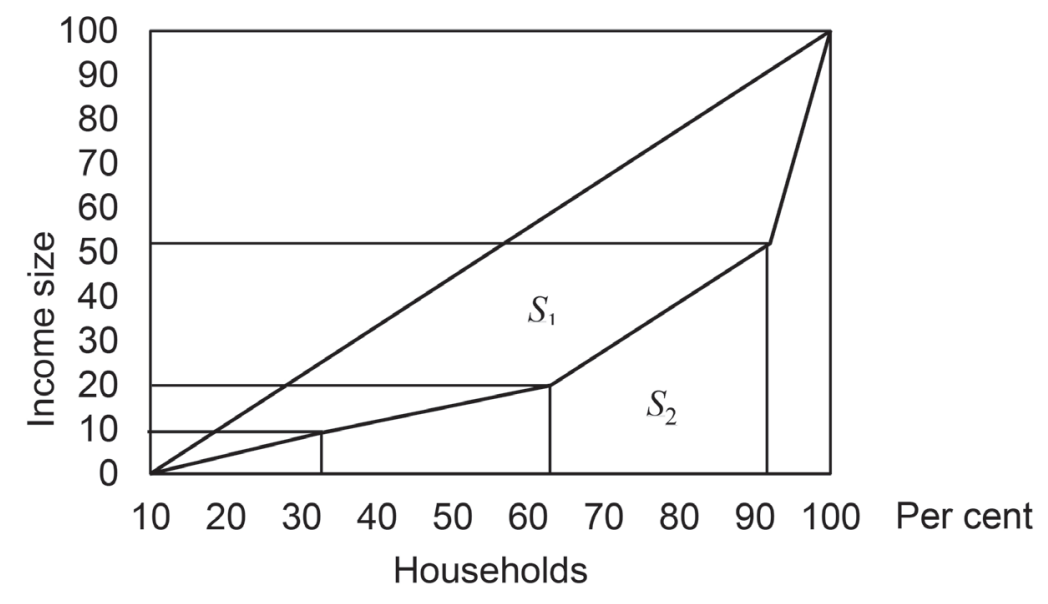


order in which it is constructed allow it to be applied to assess the homogeneity of the country's economic development. Its order would be as follows.

First, let us draw a square with sides $100 \times 100$ and its diagonal. The cumulative values of the economic development during the time spans of the period under review, expressed as a percentage, are plotted on the abscissa axis, and the percentage of the actual development of the time periods are plotted on the ordinate axis. The intersection of each of these deciles will give a particular point. Connecting the points in a straight line gives a Lorenz curve. It reflects upon the actual course of the process of economic development over the period under consideration, and the diagonal of the square represents its ideal development.

The Lorenz curve is very widely applied in mathematics, especially in economic statistics. It is suitable for examining the inequalities of a wide variety of phenomena represented by interval lines. Its degree is represented by the convexity of the curve, e.g. the distance from the diagonal of the square; the steeper the magnitude curve is, the lesser the distance from the curve it shows; the less it is distant from the diagonal, the lesser the diversification of the distribution is, and vice versa, as the curve moves away from the diagonal, the distribution irregularity increases.

The Gini coefficient (Dagum, 1980; Gursky, 2001; Rudzkienè, 2005) is used to estimate quantitative distribution comparisons based on Lorenz curve. It is determined as follows (Fig. 2):

$$
G=\frac{S_{1}}{S_{1}+S_{2}}
$$

The smaller the distribution irregularity is, which means the closer the curve is to the diagonal of the square, the lower the value of the factor $G$ we see.

If we equate the area $S_{1}+S_{2}$ to $S$, then from Fig. 2. follows that $S_{1}=S-S_{2}$. Then

$$
G=1-\frac{S_{2}}{S}
$$

In our case, when the case of quantifying the dynamics of SES economic development is under review, the smaller the variation in development and the closer the Lorenz curve approaches the square of the square, the more even the expansion is, so the Gini coefficient must be transformed in this way.

$$
\mathrm{TG}=1-G=\frac{S_{2}}{S}
$$

Here TG is the coefficient describing the continuity of SES economic development.

Fig. 1 and formulas (4) and (5) show that in ideal case of development, $S_{1}=0$, and $\mathrm{TG}=1.0$.

Quantitative assessment of the economic development dynamics of the countries concerned was carried out on the basis of the above methodology.

\section{Quantifying Economic Development Dynamics in Countries}

As stated above, we quantify the dynamics of the country's economic development on the basis of per capita GDP. Its fluctuations in the particular time spans of the period under consideration may be very uneven (Tab. 1, Fig. 1). The same representative countries - Italy and Switzerland - are taken for the calculations. From Fig. 1 it is seen that Switzerland is undergoing intense development, whereas Italy is experiencing stagnation in its development. On the other hand, in Italy, development is stable, with no major fluctuations, while in Switzerland, fluctuations are significantly higher. Therefore, it can be assumed that there is a relationship between development intensity and sustainability, which means that the intensity influences the uniformity. From a methodological point of view, it would be advantageous to eliminate the influence of intensity from the indicator of sustainable development and to evaluate it later, when a complex sustainable development indicator is created. Otherwise, the low level of development may be offset by its high intensity and result in an inadequate picture.

The different economic development situations of the countries in Fig. 1 need to be quantified. To that end, it is first of all necessary to determine the development situation in relation to which the actual situation will be assessed. In other words, we need to have a benchmark for development continuity or an ideal development case. This can be said to be the case when the 


\section{Economics}

\section{Fig. 3: Ideal case of SES dynamics of development}

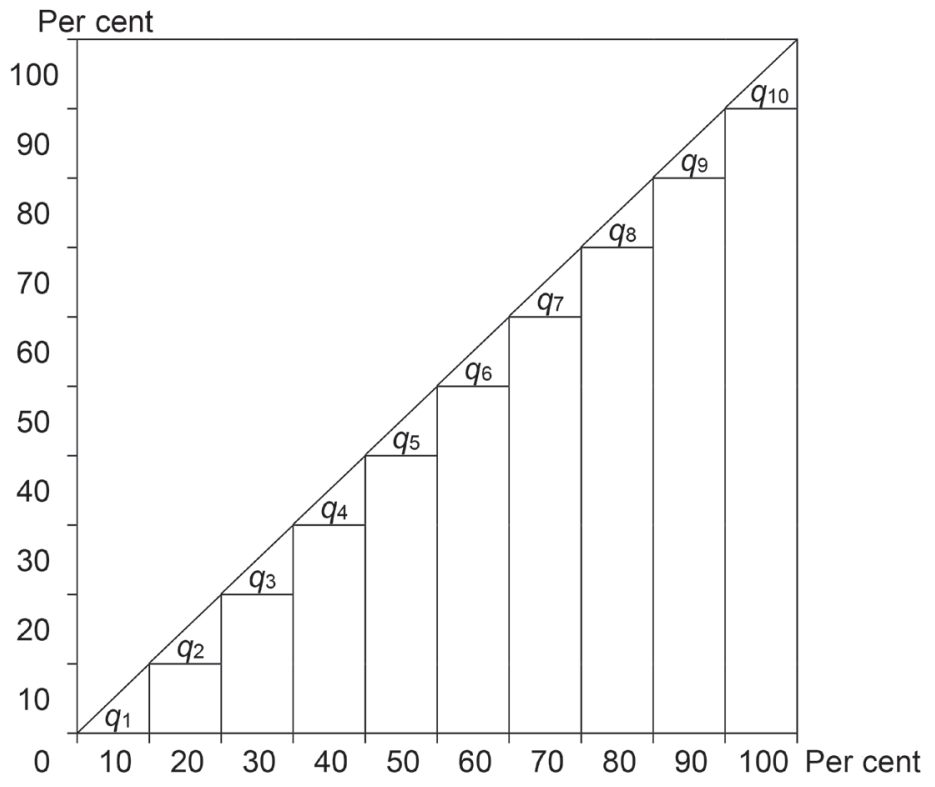

Source: own

SES development increment over the same period of time, such as the year, is the same. In this case, the development trajectory will coincide with the diagonal of the square (Fig. 1), and the development itself will look like this (Fig. 3).

From Fig. 3 it can be seen that the

\section{Fig. 4: Changes in development over time span $i ; t_{i}, t_{i}+1$ of the period under review}

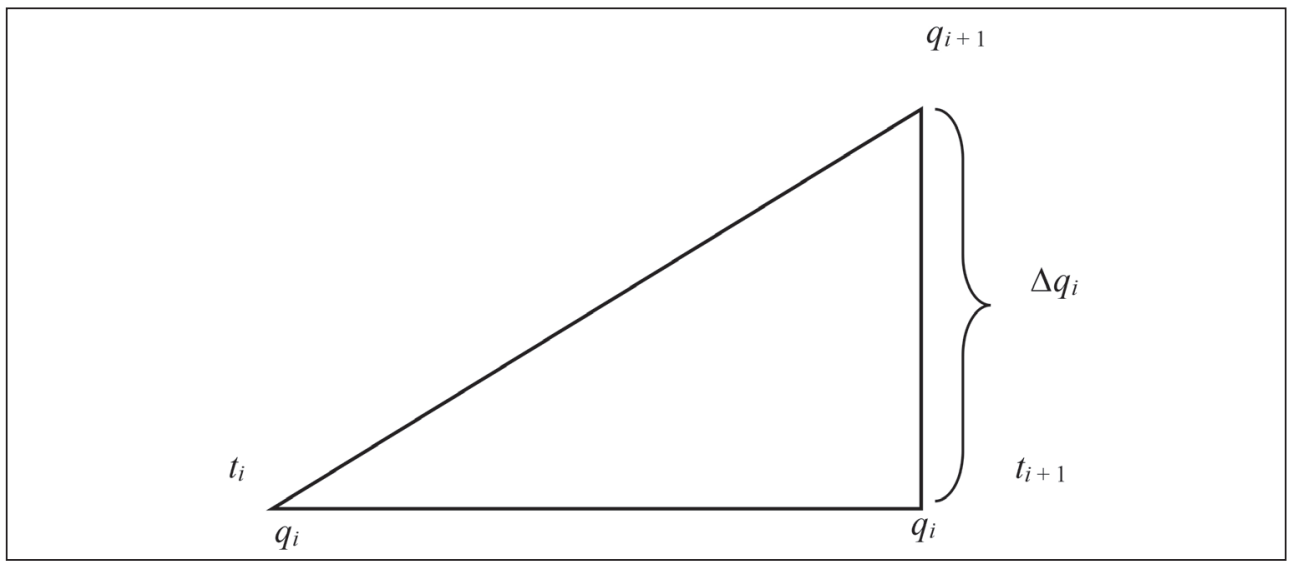

Source: own based on Ginevičius et al., 2018 
uniformity of SES development runs ideally $\Delta q_{i}=\Delta q_{i+1}$ (where $\Delta q_{i}$ is the increase in development of the time period $i$ ). In real life we usually see a situation where $\Delta q_{i} \neq \Delta q_{i+1}$, which means we see greater or lesser fluctuations in development over particular time periods of the period under review. In this case, the uniformity of development can be quantified based on the developmental differences of these periods $\Delta \Delta q=q_{i}-q_{i+1}$ (Fig. 4).
We express the variations in the economic development of the countries shown in Fig. 1 by the Lorenz curve. For this purpose, we will use Tab. 1 to calculate the absolute magnitudes of development differences between adjacent time periods (Tab. 2).

We will present the differences in Tab. 2 in ascending order. Such a procedure is possible because it will not affect the area $S_{2}$ of the Lorenz curve $S_{2}$, and the area $S_{1}$ (Tab. 3).

Based on Tab. 3, we determine the relative weight of the differences as a percentage (Tab. 4).

\section{Tab. 2: \\ Differences in economic development of the countries concerned over the periods considered}

\begin{tabular}{l|c|c|c|c|c|c|c|c|c|c}
\multirow{2}{*}{ Country } & \multicolumn{10}{c}{ Years } \\
\cline { 2 - 13 } & $\mathbf{2 0 0 8}$ & $\mathbf{2 0 0 9}$ & $\mathbf{2 0 1 0}$ & $\mathbf{2 0 1 1}$ & $\mathbf{2 0 1 2}$ & $\mathbf{2 0 1 3}$ & $\mathbf{2 0 1 4}$ & $\mathbf{2 0 1 5}$ & $\mathbf{2 0 1 6}$ & $\mathbf{2 0 1 7}$ \\
\hline Italy & 0.2 & 1.2 & 0.4 & 0.5 & 0.6 & 0.2 & 0.2 & 0.5 & 0.7 & 0.6 \\
\hline Switzerland & 3.1 & 0.9 & 5.9 & 7.6 & 1.3 & 0.9 & 1.2 & 8.7 & 1.6 & 0.2 \\
\hline
\end{tabular}

Tab. 3:

Ascending order of economic development differences between countries for the period under review

\begin{tabular}{l|c|c|c|c|c|c|c|c|c|c|c}
\multirow{2}{*}{ Country } & \multicolumn{10}{|c|}{ Years } & \multirow{2}{*}{ Total } \\
\cline { 2 - 14 } & $\mathbf{1}$ & $\mathbf{2}$ & $\mathbf{3}$ & $\mathbf{4}$ & $\mathbf{5}$ & $\mathbf{6}$ & $\mathbf{7}$ & $\mathbf{8}$ & $\mathbf{9}$ & $\mathbf{1 0}$ & \\
\hline Italy & 0.2 & 0.2 & 0.2 & 0.4 & 0.5 & 0.5 & 0.6 & 0.6 & 0.7 & 1.2 & 5.1 \\
\hline Switzerland & 0.2 & 0.9 & 0.9 & 1.2 & 1.3 & 1.6 & 3.1 & 5.9 & 7.6 & 8.7 & 31.4 \\
\hline
\end{tabular}

Source: own

Tab. 4:

Comparative weights of differences in economic development of the countries concerned over the period of time in per cent

\begin{tabular}{|l|c|c|c|c|c|c|c|c|c|c|c}
\multirow{2}{*}{ Country } & \multicolumn{10}{|c|}{ Years } & \multirow{2}{*}{ Total } \\
\cline { 2 - 14 } & $\mathbf{1}$ & $\mathbf{2}$ & $\mathbf{3}$ & $\mathbf{4}$ & $\mathbf{5}$ & $\mathbf{6}$ & $\mathbf{7}$ & $\mathbf{8}$ & $\mathbf{9}$ & $\mathbf{1 0}$ & \\
\hline Italy & 3.9 & 3.9 & 3.9 & 7.8 & 9.8 & 9.8 & 11.8 & 11.8 & 13.8 & 23.5 & 100 \\
\hline Switzerland & 0.6 & 2.9 & 2.9 & 3.8 & 4.1 & 5.1 & 9.9 & 18.8 & 24.2 & 27.7 & 100 \\
\hline
\end{tabular}

Tab. 5:

Cumulative values of comparative weights of differences in economic development of the countries under review for the considered period

\begin{tabular}{l|c|c|c|c|c|c|c|c|c|c}
\multirow{2}{*}{ Country } & \multicolumn{10}{c}{ Years } \\
\cline { 2 - 12 } & $\mathbf{1}$ & $\mathbf{2}$ & $\mathbf{3}$ & $\mathbf{4}$ & $\mathbf{5}$ & $\mathbf{6}$ & $\mathbf{7}$ & $\mathbf{8}$ & $\mathbf{9}$ & $\mathbf{1 0}$ \\
\hline Italy & 3.9 & 7.8 & 11.7 & 19.5 & 29.3 & 39.1 & 50.9 & 62.7 & 76.5 & 100 \\
\hline Switzerland & 0.6 & 3.5 & 6.4 & 10.2 & 14.3 & 19.4 & 29.3 & 48.1 & 72.3 & 100 \\
\hline
\end{tabular}




\section{Economics}

\section{Fig. 5: Lorenz curve of Italian economic development}

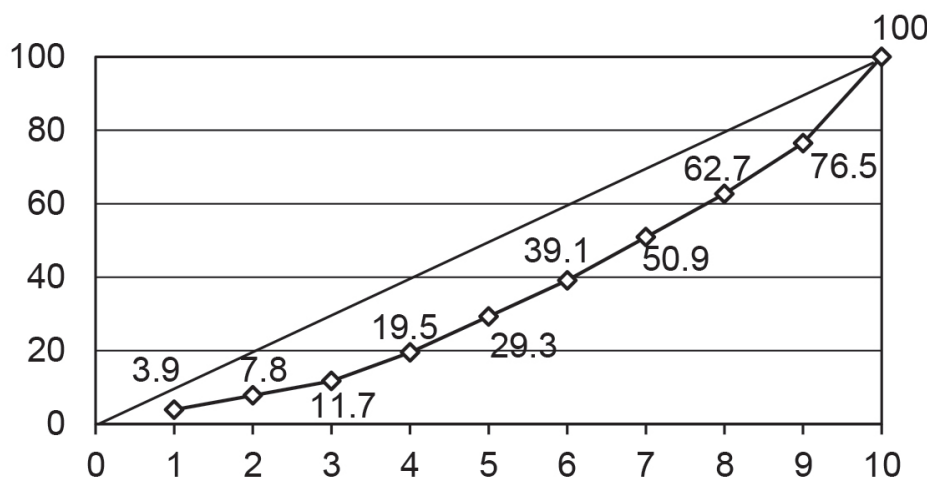

Source: own

\section{Fig. 6: Lorenz curve of Swiss economic development}

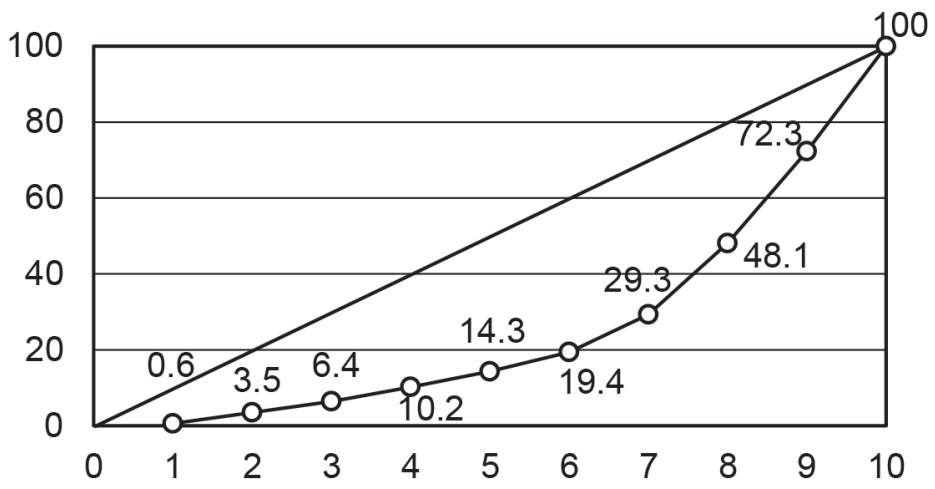

Source: own

Based on Tab. 4, we determine the cumulative values of the weights.

Based on Tab. 5, we can draw the Lorenz curves of the economic development of the countries under consideration (Fig. 5-6).

The question is how to assess the state of SES development continuity based on these results. The literature provides the following Gini coefficient rating scale (Lando et al., 2018; Lyon et al., 2016) (Tab. 7).
Based on Tab. 7 and formula (2), it is possible to provide the following scale for assessing the sustainability of economic development in a country (Tab. 8).

Tab. 8 shows that Italy has a moderate degree of economic development and Switzerland a low degree of sustainability.

The TG factor of countries' economic development underestimates its intensity. Meanwhile, from Fig. 1. it can be judged to 


\section{Tab. 6: Results of the calculation of development dynamics of the analyzed countries for 2008-2012}

\begin{tabular}{l|c|c}
\multirow{2}{*}{ Country } & \multicolumn{2}{|c}{ Coefficient } \\
\cline { 2 - 3 } & G & TG \\
\hline Italy & 0.30 & 0.70 \\
\hline Switzerland & 0.49 & 0.51 \\
\hline
\end{tabular}

\section{Tab. 7: Grading of Gini coefficient according to uniformity of data distribution}

\begin{tabular}{c|c} 
Gini coefficient value G & Conclusion \\
\hline$G<0.25$ & Very low level \\
\hline $0.25 \leq G \leq 0.35$ & Average level \\
\hline$G>0.35$ & High level \\
\hline
\end{tabular}

Source: own

\section{Tab. 8: Coefficient TG gradation by homogeneity}

\begin{tabular}{c|c} 
Value of coefficient TG & Conclusion \\
\hline$T G>0.75$ & Very high degree of dynamics of development \\
\hline $0.75>T G>0.65$ & Average degree of dynamics of development \\
\hline$T G<0.65$ & Low degree of dynamics of development
\end{tabular}

Source: own

influence uniformity. The integrative size of these two aspects of development will give a snapshot. It can be set up as follows:

$$
\widetilde{D_{l}}=\sqrt{K_{p i} T G_{i}}
$$

where $\widetilde{D_{l}}$ is the index of economic development dynamics of country $i ; K_{p i}$ is the rate of economic development intensity of country $i$; and $T G_{i}$ is the coefficient of homogeneous of economic development of country.

It is found that Italy equals 1.03 and Switzerland 1.47. On this basis, an integral index of their economic development dynamics can be calculated. It is 0.85 in Italy and 0.87 in Switzerland.

Such results of economic development dynamics of the countries are received by considering that the uniformity and intensity of development are equally significant in terms of dynamics. The situation would change substantially if we consider the importance of the partial indicators $T G$ and $K_{p}$. It can be assumed that short-term fluctuations in economic development over individual time periods (years) of the period under review have a significantly lesser impact on the state of social development of the country compared to the intensity of development covering the whole period under review. Experts estimated the importance of development intensity to its dynamics at 70 per cent out of 100 , and fluctuations in uniformity at 30 per cent. In this case, a generalized indicator of the dynamics of a country's economic development can be determined by a multi-criteria evaluation, for example, by the SAW method, which is expressed as follows (Hwang \& Yoon, 1981):

$$
D_{i}=\sum_{i=1}^{n} w_{i} \tilde{q}_{i}
$$

here $D_{i}$ is an index of country's $i$ dynamics of economic growth; $w_{i}$ is an importance of country's index of dynamics of economic growth 
( $\sum_{i=1}^{n} w=1 ; i=\overline{1, n}, n$ is a number of indices); and $\tilde{q}_{i}$ is a normalized (dimensionless) value of index $i$ of development dynamics indicator.

According to formula (7), the value of the index of dynamics of economic development of Italy is equal to 0.14 and that of Switzerland is 0.48. y. 3.43 times higher.

The proposed methodology for quantifying development dynamics is universal. It can be applied to the analysis of socioeconomic phenomena and process dynamics of any level and nature.

\section{Conclusions}

An essential condition for the competitiveness of countries is their economic development. It can be described in two aspects - intensity and uniformity. Development intensity is the rate of development growth over the period under review, and development continuity is the magnitude of development fluctuations over individual time spans (years) of the period under review. These two values can be viewed as partial indicators of the same process. The overall development process is reflected in its dynamics, which combine these indicators.

The country's economic development is reflected in GDP per capita. It is a reliable indicator of success, reflecting upon the level of economic development achieved in the country. It also allows countries to be compared according to their degree of economic development dynamics.

Methods based on dynamic analysis of processes, e.g. those who can assess the magnitude of the fluctuation of the process under consideration, an essential feature of the smoothness of development. These include coefficients derived from the Lorenz curve. The best known is the Gini coefficient. The smaller the distribution irregularity, the smaller the coefficient value. The opposite value is needed to measure the SES economic development because the larger the unevenness of distribution, the smaller the value of the indicator that reflects it. The calculations show that Italy has a moderate degree of economic development, and Sweden has a low degree of sustainability.

The indicator of economic development sustainability is strongly influenced by the development intensity, therefore the value of intensity indicator of the economic development is about 30 per cent higher than the value of the sustainability indicator.

The proposed methodology for quantifying development dynamics is universal. It can be applied to the analysis of the development of socioeconomic systems and processes at any level and kind.

\section{References}

Amin, S. (1996). Economic, social and political distortions in the modern world. Retrieved April 10, 2020, from http://www. ismea.org/INESDEV/Amin.eng.html

Atkinson, A. B., Cantilton, B., \& Marlier, R. (2002). Social Indicators. The EU and the Social Exclusion. Oxford: Oxford University Press.

Babu, S. S., \& Datta, S. K. (2015). Revisiting the link between socio-economic development and environmental status indicators focus on panel data. Environment, Development and Sustainability, 17(3), 567-586. https://doi. org/10.1007/s10668-014-9561-6

Boggia, A., \& Cortina, C. (2010). Measuring sustainable development using a multi-criteria model: A case study. Journal of Environmental Management, 91(11), 2301-2306. https://doi. org/10.1016/j.jenvman.2010.06.009

Bolcárová, P., \& Kološta, S. (2015). Assessment of sustainable development in the EU 27 using aggregated SD index. Ecological indicators, 48, 699-705. http://dx.doi. org/10.1016/j.ecolind.2014.09.001

Bratčikovienè, N., \& Deveikytè, R. (2006). Namų ūkių pajamos ir išlaidos. Lietuvos ekonominè ir socialinè raida. Retrieved February 12, 2020, from https://osp.stat.gov. It/lietuvos-statistikos-metrastis/lsm-2019/ gyventojai-ir-socialine-statistika/namu-ukiupajamos-ir-gyvenimo-salygos

Charsan, S. (2013). Assessing the sustainable development of Thailand. Procedia Environmental Sciences, 17, 611-619. https://doi.org/10.1016/j.proenv.2013.02.077

Čiegis, R., Ramanauskienè, J., \& Šimanskienè, L. (2010). Lietuvos regiony darnaus vystymosi vertinimas. Klaipèda: Klaipèdos universiteto leidykla.

Čiulevičienè, V., Čiulevičius, J., \& Šiuliauskienè, D. (2006a). Kaimo namų ūkio pajamų nelygybès statistinio vertinimo tobulinimas. Vagos: LžŪU mokslo darbai, 73(26), 73-82. 
Čiulevičienè, V., Čiulevičius, J., \& Šiuliauskienè, D. (2006b). Vartojimo išlaidų nelygybès statistinio vertinimo metodologiniai aspektai. Apskaitos ir finansu mokslas ir studijos: problemos ir perspektyvos, (1), 34-40.

Čiulevičius, J., \& Čiulevičienè, V. (2008). Lietuvos gyventojų ekonominè nelygybè ir jos ivertinimo tobulinimas. Vadybos mokslas ir studijos-kaimo versly ir jų infrastruktūros plètrai, 12(1), 46-53.

Dagum, C. (1980). The generation and distribution of income, the Lorenz curve and the Gini ratio. Economie Appliquée, 33(2), 327-367.

Ginevičius, R., Gedvilaitè, D., Stasiukynas, A., \& Šliogerienè, J. (2018). Quantitative assessment of the dynamic of the economics development of socioeconomic systems based on the MDD method. Inzinerine ekonomika - Engineering Economics, 29(3), 531-553. https://doi.org/10.5755/j01.ee.29.3.20444

Gursky, D. B. (2001). The past, present and future of social inequality, In Social stratification: class, race and gender in sociological perspective. Boulder, CO: Westview Press.

Hwang, C. L., \& Yoon, K. (1981). Multiple attribute decision making. Methods and applications a state-of-the-art survey. Lecture notes in economics and mathematical systems 186. Berlin, Heidelberg: Springer.

Ibragimov, M., Ibragimov, R., Kattuman, P., \& Ma, J. (2018). Income inequality and price elasticity of market demand: the case of crossing Lorenz curves. Economic Theory, 65, 729-750. https://doi.org/10.1007/s00199-0171037-0

Jann, B. (2016). Estimating Lorenz and Concentration Curves. The Stata Journal, 16(4), 837-866. https://doi. org/10.1177/1536867X1601600403

Kawachi, I., \& Kennedy, B. P. (1999). Income inequality and health: pathways and mechanisms. Health Services Research, 34(1 Pt 2), 215-227.

Kawachi, J., Kennedy, B. P., \& Wilkinson, R. G. (1999). Income inequality and health. New York, NY: New York Press.
Kurowska-Pysz, J., SzczepańskaWoszczyna, K., Štverková, H., \& Kašík, J. (2018). The catalysts of cross-border cooperation development in Euroregions. Polish Journal of Management Studies, 18(1), 180-193.

Lando, T., Staníčková, M., \& Franek, J. (2018). Parametric families for the Lorenz Curve: an analysis of income distribution in European countries. Ekonomická revue-Central European Review of Economic Issues, 21, 51-60. https://doi.org/10.7327/cerei.2018.06.03

Lazutka, R. (2003). Gyventojų pajamų nelygybè. Filosofija. Sociologija, 2, 53-64.

Lyon, M., Cheung, L. C., \& Gastwirth, J. L. (2016). The advantages of using group means in estimating the Lorenz Curve and Gini Index from grouped data. The American Statistician, 70(1), 25-32. https://doi.org/10.1080/00031305 .2015 .1105152

Prascevic, N., \& Prascevic, Z. (2017). Application of fuzzy AHP for ranking and selection of alternatives in construction project management. Journal of Civil Engineering and Management, 23(8), 1123-1135. https://doi.org /10.3846/13923730.2017.1388278

Rudzkienè, V. (2005). Socialinè statistika. Vilnius: MRU Publishing Center.

Song, Y., Yao, S., Yu, D., \& Schen, Y. (2017). Risky multi-criteria group decision on green capacity investment projects based on supply chain. Journal of Business Economics and Management, 18(3), 355-372. https://doi. org/10.3846/16111699.2017.1331461

Turskis, Z. (2018). A comparative study of integrated FMCDM methods for evaluation of organizational strategy development. Journal of Business Economics and Management, 19(2), 360-381. https://doi.org/10.3846/ jbem.2018.5683

Turskis, Z., Morkūnaitè, Z., \& Kutut, V. (2017). A hybrid multiple criteria evaluation method of ranking of caltural heritage strucrues for renovation projects. International Journal of Strategic Property Management, 21(3), 318-329. https://doi.org/10.3846/164871 5X.2017.1325782 